\title{
The Right to be Free from Economic Coercion
}

\author{
Antonios Tzanakopoulos*
}

\begin{abstract}
This article seeks to determine if there is a fundamental right of states to be free from economic coercion, against the background of international law permitting economic coercion as a means for its own implementation. After defining coercion and other cognate terms, the article surveys the limits to (economic) countermeasures and (economic) sanctions, and determines that any 'sphere of economic freedom' of states is essentially a relative concept, without an irreducible core. Public international law does not currently establish a fundamental right of states to be free from economic coercion-though one should probably be established.
\end{abstract}

\section{Keywords}

Fundamental Rights of States, Freedom, Coercion, Economic Coercion, Countermeasures, Sanctions, Intervention

\section{Introduction}

The element of coercion, the coercive sanction, is a fundamental attribute of positive law; ${ }^{1}$ its coercive force is what distinguishes law from other normative systems, such as morals. ${ }^{2}$ In the highly centralised domestic legal order, it is the state itself that has the power to impose coercive sanctions in accordance with the law. By contrast, in the decentralised international legal orders, the coercive sanction is a faculty left to the (directly or indirectly) injured state to impose. ${ }^{3}$ The coercive sanctions of international

* Associate Professor of Public International Law, University of Oxford; Fellow, St Anne's College, Oxford (UK). Many thanks are due to Eleni Methymaki and Anna Ventouratou for their excellent research assistance, as well as to the participants in the 'Rights of States' workshop at the University of Alabama, School of Law, in April 2015, for their useful comments. The usual disclaimer applies.

1 See Hans Kelsen, Introduction to the Problems of Legal Theory: A Translation of the First Edition of the Reine Rechtslehre or Pure Theory of Law (B Litschewski Paulson and SL Paulson trs, OUP 1997) 26.

2 For a thorough, though critical, analysis of Kelsen's approach to the interplay between the national and the international legal order, see generally François Rigaux, 'Hans Kelsen on International Law' (1998) 9 EJIL 325.

3 See, eg, International Law Commission (ILC), Responsibility of States for Internationally Wrongful Acts, UNGA Res 56/83 (28 January 2002) UN Doc A/RES/56/83 (ILC Articles on State Responsibility) arts 42, 48. The term 'indirectly' injured state is used here to denote art 48's 'State other than the injured State'. See Linos-Alexander Sicilianos, 'The Classification of Obligations and the Multilateral Dimension of the Relations of International Responsibility’ (2002) 13 EJIL 1127, 1138. 
law have, traditionally, been reprisals and war. ${ }^{4}$ War, and the use of force in general, have now been blanket-banned by virtue of the Charter of the United Nations (UN Charter) - with the sole exception of self-defence ${ }^{5}$ - and thus there may have emerged something like a qualified right to peace. ${ }^{6}$

Reprisals, however, are still around in the guise of countermeasures, ${ }^{7}$ and countermeasures are predominantly economic in nature. ${ }^{8}$ Although officially their aim is to 'induce' a state that has become responsible for a violation of international law to resume compliance with its international obligation(s), ${ }^{9}$ such 'inducement' does not take place with sweet talk, but with coercive (economic) force.

Already, then, it appears difficult to consider that there is a fundamental right of states to be free from economic coercion. This is because at the very same time there seems to exist a fundamental right (faculty) of states to use economic coercion in order to enforce international law, ie to implement the international responsibility of states that have perpetrated an internationally wrongful act. The aim of such coercive measures is to induce responsible states (to force them, coerce them) to comply with their (secondary) obligations of cessation and reparation. Put differently, international law prohibits forms of (economic) coercion in the guise of primary rules, but precludes the wrongfulness of forms of (economic) coercion in the guise of secondary rules. ${ }^{10}$ This apparent contradiction seems non-survivable: at best there may be a qualified, relative right to be free from economic coercion, not a fundamental one. Yet, this may only be an apparent contradiction; it all comes down to what exactly is meant by 'coercion'.

At the same time, the emergence of international organisations, and in particular the $\mathrm{UN}$, makes it even more difficult to conceptualise a fundamental right of states to be free

4 See Hans Kelsen, Reine Rechtslehre (2nd edn, Franz Deuticke 1960) 324-28. According to Kelsen, war and reprisals are the sanctions which allow international law to qualify as a legal order. See also Hans Kelsen, The Legal Process and International Order (2nd edn, Royal Institute of International Affairs 1935) 13 ('Anyone who rejects the theory of the just war denies, indeed, the legal nature of international law'); Rigaux (n 2) 335.

5 See Charter of the United Nations (adopted 26 June 1945, entered into force 24 October 1945) 1 UNTS XVI (UN Charter) arts 2(4), 51.

6 A qualified right, given that a state may be subject to measures involving the use of armed force 'authorised' by the UN Security Council in accordance with art 42 UN Charter.

7 For the change of terminology from 'reprisals' to the more neutral term 'countermeasures', and for a short history of how the term became established through its adoption by arbitral tribunals, the International Court of Justice (ICJ) and the ILC, see, eg, Elisabeth Zoller, Peacetime Unilateral Remedies: An Analysis of Countermeasures (Transnational Publishers 1984) xv-xvii; of Jean-Claude Venezia, 'La Notion de Représailles en Droit International Public' (1960) 64 RGDIP 466.

8 See, eg, UN Charter, art 41. See also ILC, Draft Articles on the Responsibility of States for Internationally Wrongful Acts, with Commentaries (2001) ILC YB 2001/II(2) (ILC Articles on State Responsibility Commentaries) commentary to art 30,89, paras 3, 5, referring to 'complete or partial interruption of economic relations' and generally to economic reprisals as the predominant example of countermeasures not involving the use of force.

9 ILC Articles on State Responsibility, art 49.

10 cf Linos-Alexander Sicilianos, Les Réactions Décentralisées à l'Illicite: Des Contre-mesures à la Légitime Défense (LGDJ 1990) 252. 
from economic coercion. Under chapter VII of the UN Charter, and in particular article 41, the UN Security Council may impose 'sanctions,, ${ }^{11}$ or properly so-called 'measures not involving the use of armed force' on states (and other actors) in response to a threat to the peace, breach of the peace, or act of aggression determined in accordance with article 39. Of these sanctions, economic sanctions are paradigmatic, and are indeed referred to specifically in the non-exhaustive enumeration of article $41 .{ }^{12}$ The power of the UN to impose such economic sanctions, ie to employ coercive economic power against a state, would also contradict a fundamental right of states to be free from economic coercion. And again here the question of the meaning of 'coercion' is key.

The first step must be to define the term 'coercion' properly, so as to understand what economic coercion means, and so as to distinguish it from other cognate concepts (section two). The next step is to determine whether, and to what extent, states have a fundamental right to be free from economic coercion by looking at how this (for now presumed) right may interact with the faculty of states to take economic countermeasures in order to enforce international law (section three) and with the power of the UN to impose economic sanctions in order to enforce the peace (section four). Section five, then, seeks to determine whether there is any essential and irreducible sphere of freedom of states which contains the right to be free from economic coercion, over and beyond the analysis of the law on countermeasures and sanctions.

\section{The meaning of (economic) coercion}

The problem begins with the use of terms. What is coercion, and how does it differ-if at all-from 'interference, for example, or 'intervention'? How does it relate to 'sovereignty' (assuming one understands exactly what sovereignty means) and the 'domaine réservé, ${ }^{13}$ the reserved domain of exclusive jurisdiction of states? How close together, even intertwined, these concepts are is evident in the following quote from the 1970 Friendly Relations Declaration:

11 The term 'sanctions' does not appear in the UN Charter, but it has become commonplace to refer to art 41's measures as sanctions. ILC Articles on State Responsibility Commentaries (n 8) (the commentary to art 30 acknowledges the use of the term 'sanctions' as alternative to the term 'countermeasures' in practice); see also ibid 128, para 3, where however

The term 'sanction' is also often used as equivalent to action taken against a State by a group of States or mandated by an international organization. But the term is imprecise: Chapter VII of the Charter of the United Nations refers only to 'measures', even though these can encompass a very wide range of acts, including the use of armed force (Articles 39, 41 and 42).

12 According to the UN Charter, art 41, the measures not involving the use of armed force that the UN Security Council may impose 'include complete or partial interruption of economic relations'.

13 For the concept and definition of 'domaine réservé, as well as its interrelation with the concept of state sovereignty, see Katja S Ziegler, 'Domaine Réservé' in Rüdiger Wolfrum (ed), Max Planck Encyclopedia of Public International Law (OUP 2012) para 1: 'the domaine réservé describes areas where States are free from international obligations and regulation'. 
No State may use or encourage the use of economic (...) measures to coerce another State in order to obtain from it the subordination of the exercise of its sovereign rights and to secure from it advantages of any kind. Also, no State shall [seek to overthrow the regime] or interfere in civil strife in another State. The use of force to deprive peoples of their national identity constitutes a violation of their inalienable rights and of the principle of non-intervention. Every State has an inalienable right to choose its political, economic, social and cultural systems, without interference in any form by another State. ${ }^{14}$

In Nicaragua, the International Court of Justice (ICJ) put the terms into some perspective, and it repays quoting the Court at length:

[I] $\mathrm{n}$ view of the generally accepted formulations, the principle [of non-intervention] forbids all States or groups of States to intervene directly or indirectly in internal or external affairs of other States. A prohibited intervention must accordingly be one bearing on matters in which each State is permitted, by the principle of State sovereignty, to decide freely. One of these is the choice of a political, economic, social and cultural system, and the formulation of foreign policy. Intervention is wrongful when it uses methods of coercion in regard to such choices, which must remain free ones. The element of coercion, which defines, and indeed forms the very essence of, prohibited intervention, is particularly obvious in the case of an intervention which uses force, either in the direct form of military action, or in the indirect form of support for subversive or terrorist armed activities within another State. ${ }^{15}$

According to the ICJ, there is a certain sphere of freedom of the state to act in any way that it wishes, which is protected by international law. That sphere of freedom seems to emanate from the sovereignty of the state in a way that is reminiscent of the Lotus case: to the extent that a state has not assumed an obligation to act in any particular way, it is free to act in any way that it wants. ${ }^{16}$ That sphere includes the free choice of political, economic, social and cultural system, and the formation of foreign policy, ${ }^{17}$ presumably because no state has subjected or may subject these to international legal obligations.

14 Declaration on Principles of International Law concerning Friendly Relations and Co-operation among States in accordance with the Charter of the United Nations, UNGA Res 2625 (XXV) (24 October 1970) UN Doc A/RES/25/2625 (emphasis added). Similar provisions are to be found in further UN General Assembly Resolutions, such as the Declaration on the Inadmissibility of Intervention in the Domestic Affairs of States and the Protection of their Independence and Sovereignty, UNGA Res 2131 (XX) (21 December 1965) UN Doc A/RES/20/2131; Declaration on the Inadmissibility of Intervention and Interference in the Internal Affairs of States, UNGA Res 31/91 (14 December 1976) UN Doc A/RES/31/91. The Charter of the Organization of American States also includes a relevant provision in art 20, according to which ' $[n]$ o State may use or encourage the use of coercive measures of an economic or political character in order to force the sovereign will of another State and obtain from it advantages of any kind': Charter of the Organization of American States (adopted 30 April 1948, entered into force 13 December 1951) 119 UNTS 48 (OAS Charter).

15 Military and Paramilitary Activities in and against Nicaragua (Nicaragua $v$ United States of America) (Merits) [1986] ICJ Rep 14 (Nicaragua) 98, para 205; cf 114, para 241.

16 SS 'Lotus' (France v Turkey) (Merits) PCIJ Rep Series A No 10, 18-19: 'Restrictions upon the independence of States cannot (...) be presumed'; 'In these circumstances, all that can be required of a State is that it should not overstep the limits which international law places upon its jurisdiction; within these limits, its title to exercise jurisdiction rests in its sovereignty.'

17 On this, see further section five below. 
This is much reminiscent of a concept of 'domaine réservé' that is defined negatively, ${ }^{18}$ ie in a residual manner-that which remains within the sphere of free action of the state is simply that on which the state has not assumed an international obligation to act in any particular way. ${ }^{19}$ But a state could assume obligations on any matter, and there are no matters that necessarily fall within some sort of hard core of sovereignty or freedom of action which the state cannot freely dispose of, as the ICJ itself has said in the past. ${ }^{20}$ Intervention into this reserved domain is prohibited: a state may not be coerced to act in a particular manner on issues within its sphere of freedom. Coercion is a method of illegal intervention, the ICJ says in Nicaragua, but then immediately equates the two: coercion is intervention. Seeking to coerce a state within its sphere of freedom is wrongful; it constitutes intervention. Merely interfering with a state's choices within its sphere of freedom and applying relevant pressure without breaching any obligations is lawful, as long as it does not amount to coercion and, thus, intervention. ${ }^{21}$

18 Ziegler (n 13) para 2.

19 Many constitutive instruments of international organisations contain provisions safeguarding the 'reserved domain' of states from intrusion by the international organisation, usually by providing that the organisation may not intervene or interfere in matters which are (essentially) within the domestic or internal jurisdiction of the (member) states. See, eg, Covenant of the League of Nations (adopted 28 April 1919, entered into force 10 January 1920) art 15(8); Constitution of the United Nations Economic, Social and Cultural Organisation (adopted 16 November 1945, entered into force 4 November 1946) 4 UNTS 275, art I(3); OAS Charter, art 1(2); UN Charter, art 2(7); Consolidated Version of the Treaty on European Union [2012] OJ C326/15 art 5(3): these articles serve pretty much the same purpose, though implying the principle through the introduction of an exception to it. Nowhere in these texts, however, is it stated what lies 'essentially' within the domestic (or internal) jurisdiction of a state. The reason is simple: what lies within that reserved domain is difficult to determine in any way but negatively. What remains within the reserved domain is whatever states have not removed from their (exclusive) domestic jurisdiction by making it subject to conduct regulated by international law; in other words, that on which the relevant state has assumed no international obligations. This is how the Permanent Court of International Justice (PCIJ) approached the relevant terms ('solely within the domestic jurisdiction') in Nationality Decrees Issued in Tunis and Morocco (Advisory Opinion) PCIJ Rep Series B No 4 (Nationality Decrees) 24: 'The question whether a certain matter is or is not solely within the jurisdiction of a State is an essentially relative question; it depends upon the development of international relations' (emphasis added). The Court then went on to equate this to the concept of 'reserved domain' (ibid). For a confirmation by the ICJ, cf Barcelona Traction, Light and Power Company, Limited (Belgium v Spain) (New Application, Second Phase: 1962) [1970] ICJ Rep 3, 34-35, para 32.

20 The PCIJ has found that the assumption of international obligations is an exercise of sovereignty, rather than its denial. See SS 'Wimbledon' (United Kingdom v Japan) PCIJ Rep Series A No 1, 25:

The Court declines to see in the conclusion of any Treaty by which a State undertakes to perform or refrain from performing a particular act an abandonment of its sovereignty. No doubt any convention creating an obligation of this kind places a restriction upon the exercise of the sovereign rights of the State, in the sense that it requires them to be exercised in a certain way. But the right of entering into international engagements is an attribute of State sovereignty.

See further on this, with respect to the 'police powers' doctrine in international investment law, Callum Musto, States' Prescriptive Jurisdiction and the 'Police Powers' Doctrine (MPhil thesis, University of Oxford 2015).

21 In fact the Court in Nicaragua (n 15) 96, para 202, equates interference and intervention by stating that ' $\mathrm{t}$ ] he principle of non-intervention involves the right of every sovereign State to conduct its affairs without outside interference' (emphasis added). In this article, the two are considered to be separate 
This brings us no closer to defining coercion (or intervention for that matter) in any way other than negatively and residually. The difficulty, however, in defining coercion in any other way is evident also in the practice of states. Given the importance attached to the assumption of international obligations (as it reduces a state's sphere of freedom), provision should be made so that a state freely assumes any obligations limiting its sovereignty. Article 52 of the Vienna Convention on the Law of Treaties (VCLT) seeks to deal with this precise issue, namely to avoid that a state be coerced into assuming an international obligation. ${ }^{22}$ Article 52 specifically deals with the issue of coercion occurring at the time of the conclusion of the treaty, in terms of a direct causal link between the coercion and the conclusion of the treaty. It protects against a treaty being concluded through the threat or use of force. ${ }^{23}$ If there was no such safeguard at the level of assumption of obligations, one could, instead of coercing a state to do something that it does not have to do, coerce a state to assume an obligation to do what it does not want to do. From then on, any 'coercion' of the state in the relevant subject-matter would be lawful, as it would merely seek to enforce that which the state had assumed an obligation to do. ${ }^{24}$

But the coercion which renders a treaty void under article 52 VCLT is only coercion by the threat or use of force. These terms, being reminiscent of article 2(4) of the UN Charter, are predominantly interpreted as referring only to armed force, not economic force. ${ }^{25}$ Indeed, the International Law Commission (ILC) and the states during the Vienna Conference were deeply divided on whether coercion was limited to military coercion or could also extend to economic and political coercion, and they simply decided not to clearly decide the matter. ${ }^{26}$ Corten argues that the broader interpretation, which is not limited to military, but includes also economic and political coercion, has

concepts, interference being lawful pressure applied in order to affect actions within the sphere of freedom of a state, and intervention being the unlawful version of the above (see further section three below).

22 Vienna Convention on the Law of Treaties (adopted 23 May 1969, entered into force 27 January 1980) 1155 UNTS 332 (VCLT).

23 Mark Villiger, Commentary on the 1969 Vienna Convention on the Law of Treaties (Martinus Nijhoff 2009) 645. See also Kirsten Schmalenbach, 'Article 52. Coercion by a State by the Threat or Use of Force' in Oliver Dörr and Kirsten Schmalenbach (eds), Vienna Convention on the Law of Treaties: A Commentary (Springer 2012) 872 , where the author states that '[a]rt 52 stipulates that-irrespective of the subject matter-a treaty is void because of the proscribed methods that procured its conclusion. The voidness of the treaty results from the lack of free consent on the part of the coerced State' (original emphasis removed).

24 cf Jean Combacau, 'Pas une Puissance, une Liberté: La Souveraineté International de l'État' (1993) 67 Pouvoirs 47, 52-53.

25 For a discussion on whether UN Charter, art 2(4), and thus also VCLT, art 52, could and should be interpreted broadly so as to encompass economic coercion, see Villiger (n 23) 638, 642-43; Sicilianos, Les Réactions Décentralisées à l'Illicite (n 10) 248. One of the main reasons that an extended definition of coercion was not adopted was the fear that states would use it as 'a pretext to rid themselves from burdensome treaties, or that the efficacy of pacta sunt servanda and legal certainty would suffer': see Villiger (n 23) 644.

26 See on this Olivier Corten, 'Article 52-1969 Vienna Convention' in Olivier Corten and Pierre Klein (eds), The Vienna Conventions on the Law of Treaties-A Commentary (OUP 2011) 1201, 1205-11. 
prevailed nowadays. ${ }^{27}$ Be that as it may, the coercion, whether military or economic, must be unlawful in order to lead to invalidity of the treaty under article 52 VCLT. $^{28}$ The VCLT thus does not help define coercion in anything other than a relative, residual manner.

Similar problems were faced by the ILC in seeking to establish the responsibility of a state in connection with the act of another state when the former has coerced the latter to perpetrate an internationally wrongful act. The relevant provision is article 18 of the ILC Articles on State Responsibility, according to which '[a] State which coerces another State to commit an act is internationally responsible for that act if: (a) the act would be, but for the coercion, an internationally wrongful act of the coerced State; and (b) the coercing State does so with knowledge of the circumstances of the act'. Effectively the coercing state becomes responsible for the act of another state, the coerced one. So it is not the coercion per se that constitutes an internationally wrongful act and that engages the responsibility of the coercing state. Rather, the responsibility that attaches to the act of the coerced state, if that act would have been internationally wrongful for that state, is allocated to the coercing state. Indeed, the commentary is at pains to highlight that 'coercion', as meant in article 18 of the ILC Articles on State Responsibility, is not necessarily 'unlawful' coercion. ${ }^{29}$ However, the commentary fails to give even a single example of 'lawful' coercion. It merely says that practically most instances of coercion within the scope of article 18 will be unlawful, either 'because they involve a threat or use of force contrary to the Charter of the United Nations, or because they involve intervention, ie coercive interference, in the affairs of another State. ${ }^{30}$ 'Such is also the case with countermeasures', the commentary continues. ${ }^{31}$

Coercion is thus portrayed as an act that is not necessarily unlawful, but the examples given relate to wrongful acts: violation of the prohibition of the threat or use of force, and violation of the prohibition of intervention. The reference to countermeasures is important: the 'coercive' act that countermeasures by definition involve is justified-it is 'de-coercified'-by virtue of the fact that a countermeasure is in the first instance an unlawful act, whose wrongfulness is precluded because it is taken as a response to a prior wrongful act. For this reason also, 'coercing' a state by way of countermeasures to do something would not constitute coercion under article 18 of the ILC Articles on State Responsibility: the 'coerced' state can only be 'coerced' to comply with its international obligations. Otherwise the 'coercive' measure under examination is not a countermeasure, and is thus unlawful in and of itself (unless justified by some other circumstance precluding wrongfulness). ${ }^{32}$ Complying with an (already existing) international obligation, on the other hand, is not and would not be an internationally

27 ibid.

28 ibid.

29 See ILC Articles on State Responsibility Commentaries (n 8) commentary to art 18.

30 ibid (emphasis added).

31 ibid.

32 See ILC Articles on State Responsibility, arts 20-25. 
wrongful act for the coerced state, and will thus never fulfil the requirements of article 18 of the ILC Articles on State Responsibility.

To cut a very long story perhaps too short, the following observations are in order.

(a) There is no clarity as to the use of terms 'coercion', 'intervention', 'interference', and so forth. Each entity employing them, whether a state, the UN General Assembly, the ICJ, the Organization of American States, or the ILC, will cast the terms and their relationships to one another in their own special way.

(b) Having said that, the conception of the various terms by the various actors is not too far apart-there are just little differences, which however make it difficult to know exactly what one is talking about at any given time.

(c) The best that can be made out of this mess is to assert that coercion is effectively tantamount to intervention (and, if you will, to 'coercive interference' in ILC parlance), and is defined by the fact that it is unlawful because it invades a state's 'sphere of freedom'. This sphere of freedom, in turn, is defined by the fact that the state has not assumed any international obligations relating to the matters within the sphere. Any invasion into the sphere of freedom constitutes coercion/ intervention/coercive interference, namely, an unlawful act. Any other action or omission, however 'coercive' it may seem, will be mere pressure or interference, and will be perfectly lawful as long as it does not violate any international obligation of the 'coercing' state (for example, the prohibition of the threat or use of force).

This provisional understanding of 'coercion' will now be tested against an analysis of the law on (economic) countermeasures (section three) and (economic) sanctions (section four), 'coercive' acts par excellence in the international legal system.

\section{The limits of (economic) countermeasures}

The limits of economic countermeasures are the same limits that apply to all countermeasures. They can be distinguished into two categories: substantive and procedural limits. The substantive limits are reflected in articles 49-51 of the ILC Articles on State Responsibility and include: the requirement of standing; the requirement of the proper identification of the target in conjunction with a prohibition on targeting third states; the prohibition of affecting certain specified (groups of) international obligations; the requirement that the countermeasures serve a specified aim; and the requirement that the countermeasures be proportionate to ('commensurate with') the injury suffered by the reacting/(indirectly) injured state. ${ }^{33}$ Procedural limits of resorting to countermeasures

33 There are further limits spelled out in the ILC Articles on State Responsibility, art 49(2), such as that countermeasures may not lead to an abdication of the obligation being breached as a countermeasure, but 'are limited to [its] non-performance for the time being'. 
are enumerated in article 52 of the ILC Articles on State Responsibility, under the title 'Conditions relating to resort to countermeasures', and do not necessarily reflect customary international law in their entirety. ${ }^{34}$

Regarding the substantive limits enumerated above, it is useful to detail how these are arrived at. Some are indeed enumerated in the relevant provisions of the ILC Articles on State Responsibility explicitly. These are, specifically, the prohibition of countermeasures affecting certain (groups of) international obligations (article 50), and the requirement of proportionality (article 51). According to article 50, obligations regarding the use of force, obligations regarding the protection of fundamental human rights, obligations of a humanitarian character prohibiting reprisals, obligations under applicable dispute settlement procedures, and obligations regarding the inviolability of diplomatic or consular agents, premises, archives, and documents may not be affected by way of countermeasures. However, the list is open-ended: any other obligations under peremptory norms of international law may not be affected by way of countermeasures either.

This substantive limit to countermeasures could have offered an insight as to the existence of a fundamental right of states to be free from economic coercion. However, such a fundamental right or any obligations stemming from its existence is not mentioned in the list explicitly. Rather, there is a renvoi to all obligations under peremptory norms of international law, which accords with the provision of article 26 of the ILC Articles on State Responsibility, ${ }^{35}$ and which leaves open the question of whether there is a fundamental right of states to be free from economic coercion that also imposes a correlative jus cogens obligation on all states not to intrude in that sphere of freedom of the state, even by way of countermeasures. ${ }^{36}$

The requirement of proportionality relates to the injury suffered by the reacting state, and is thus only a relative limit, not an absolute one, contrary to the limit under article 50, which does not permit countermeasures affecting certain obligations under any circumstances. Assuming severe enough injury to the injured state, the countermeasure will be proportionate even when causing significant harm to the responsible state, including significant economic harm.

Further substantive limits on the taking of countermeasures stem directly from the definition of countermeasures. Since these are to be taken by an injured state, it must be established that the state resorting to countermeasures has been injured by an

34 See Antonios Tzanakopoulos, Disobeying the Security Council-Countermeasures against Wrongful Sanctions (OUP 2011) 186; Linos-Alexander Sicilianos, 'La Codification des Contre-mesures par la Commission du Droit International' (2005) 38 RBDI 447, 467.

35 ILC Articles on State Responsibility, art 26, provides that ' $\mathrm{n}$ ] othing in [the chapter relating to circumstances precluding wrongfulness, of which countermeasures is one] precludes the wrongfulness of any act of a State which is not in conformity with an obligation arising under a peremptory norm of general international law.

36 See Sicilianos, Les Réactions Décentralisées à l'Illicite (n 10) 252 where, despite arguing that a state’s right to be free from economic coercion is indeed a 'primary' rule of international law, he concludes that there is no indication of the jus cogens nature of such a rule. 
internationally wrongful act of another state. The conditions for a state being considered injured by an internationally wrongful act are spelled out in articles 42 and 48 of the ILC Articles on State Responsibility, and a detailed examination of these provisions would be too difficult within the constraints of this study. However, it should be highlighted that it is article 42 which provides specifically for the invocation of responsibility as an 'injured' state and thus permits clearly, in conjunction with the definition in article 49, the taking of countermeasures by states that qualify as 'injured' under article 42 . By contrast, article 48 refers to invocation of responsibility by states 'other than an injured State. This seems to indicate that such states are not permitted to resort to countermeasures as they are not 'injured' - they are states other than an injured state. However, article 54 of the ILC Articles on State Responsibility, a saving clause, purports to leave open the question of the entitlement of states 'other than an injured State' (which may invoke the responsibility of a responsible state under article 48) to also resort to countermeasures. Despite the ILC's claim in the relevant commentary that state practice as to the taking of such 'countermeasures in the general interest', or 'third State countermeasures', is embryonic, ${ }^{37}$ studies suggest that it is this type of countermeasures that is most prevalent in the practice of states and thus should be considered allowed, even if under strict conditions. ${ }^{38}$ In any event, the standing of a state to take countermeasures will hinge on whether that state can demonstrate standing to invoke the responsibility of the responsible state/purported target of the countermeasures, whether under article 42 or potentially also under article 48 of the ILC Articles on State Responsibility.

Since countermeasures are meant to only target a state that is responsible for an internationally wrongful act, third states are protected from potential breaches against them subsequently justified as being a countermeasure. But this does little to support any sort of fundamental right to be free from economic coercion, as the question is primarily with respect to the responsible state. Any third states simply have the right not to be targeted by countermeasures at all, and if they are, they will be able to invoke the responsibility of the state resorting to the countermeasures. ${ }^{39}$ An open question remains as to the potential indirect effects of countermeasures taken against a responsible state on the economy of a third state. The former state may have significant economic ties to the latter, and economic countermeasures against the former state may thus have an impact on the latter. However, as long as the responsible state has not violated any obligation it

37 See the ILC Articles on State Responsibility Commentaries (n 8) commentary to art 48, 129, para 8: 'Occasions have arisen in practice of countermeasures being taken by other States, in particular those identified in article 48, where no State is injured or else on behalf of and at the request of an injured State. Such cases are controversial and the practice is embryonic.' See also Alexander Orakhelashvili, Peremptory Norms in International Law (OUP 2008) 270-72.

38 See, generally, Sicilianos, 'The Classification of Obligations and the Multilateral Dimension of the Relations of International Responsibility' (n 3) 1127; Christian J Tams, Enforcing Obligations Erga Omnes in International Law (CUP 2005); Martin Dawidowicz, 'Public Law Enforcement without Public Law Standards? An Analysis of State Practice on Third-party Countermeasures and Their Relationship to the UN Security Council' (2006) 77 BYBIL 333.

39 See ILC Articles on State Responsibility Commentaries (n 8) commentary to art 49, 131, para 8. 
owes to the third state (which could not be justified as a countermeasure), the question will have to be dealt with within the context of proportionality. ${ }^{40}$

Perhaps the only promising limit imposed on resort to countermeasures stems from the definition provided for in article 49(1) of the ILC Articles on State Responsibility in as much as it determines the purpose or aim of countermeasures. These are to be taken 'only (...) in order to induce [the responsible] State to comply with its [international] obligations. ${ }^{41}$ As such, countermeasures may not be employed in order to 'induce' a state to undertake any action which it has not obligated itself to undertake by means of accepting a relevant international obligation. This means effectively that a countermeasure may never cross the line from (economic) inducement to comply with an obligation to (economic) coercion of the target state to do something it is not bound to do under international law. The lack of any clear definitional boundary between inducement and coercion leads to the conclusion that the line between the two is actually drawn by the law: being forced to do something that you have to do is merely an inducement. Being forced to do something that you have no obligation to do is coercion.

The flip side of the coin in this connection is retorsion. An act of retorsion is an unfriendly, but perfectly lawful act, which does not amount to a breach of any international obligation on the part of the state engaging in it towards the target state, even though it may be a response to an internationally wrongful act of the latter. ${ }^{42} \mathrm{An}$ act of retorsion, such as the withdrawal of voluntary economic aid, or the suspension of trade when there is no international obligation to trade, ${ }^{43}$ may clearly have economic consequences and be taken in order to put economic pressure on the target state. However, given that it is a perfectly lawful act, whatever its motivations, it can be taken at any time and without any justification on the part of the state resorting to it. ${ }^{44}$ It would then appear that economic retorsion could never amount to economic coercion: it does not in any way interfere with rights of the target state which constitute correlative obligations of the state resorting to retorsion. It is merely an exercise by the latter state of its freedom of action to the extent that it has not undertaken any obligations to give the target state economic aid, for example, or to trade with it.

One could object to this analysis of retorsion by arguing that retorsion must find an ultimate limit when it amounts to economic coercion, ie when it seeks to force the target state to do something that it is not (legally) obligated to do. But since the reacting state is not violating any obligations toward the target state, ${ }^{45}$ such an argument just assumes the existence of an obligation not to use lawful means to induce a state to do something that it does not have to do. To say then that the ultimate limit of retorsion must be the point where the action constitutes intrusion into the sphere of freedom of the target

40 The proportionality calculus could thus be made to include secondary effects on third states.

41 ILC Articles on State Responsibility, art 49 (emphasis added).

42 ILC Articles on State Responsibility Commentaries (n 8) commentary to pt three, ch II, 128, para 3.

43 See Nicaragua (n 15) 138, para 276.

44 ILC Articles on State Responsibility Commentaries (n 8) commentary to pt three, ch II, 128, para 3.

45 If it were, it would have to justify the breach as a countermeasure or in some other way. 
state from economic coercion, which is a fundamental right of states, would be a petitio principii. The ultimate limit of retorsion is the crossing into illegal action, the violation of an obligation owed to the target state. Unless the obligation not to coerce the target state is somehow demonstrated as founded in positive law, an act of retorsion can never constitute (economic) coercion.

What this discussion seeks to demonstrate is that, on an analysis of the law on (economic) countermeasures (and the associated law on acts of retorsion), the 'fundamental right to be free from economic coercion' appears to be nothing more than a function of assumed international obligations and correlative rights. A state can never be 'coerced' to do something that it has to do by means of a (lawful) countermeasure, because it has to do it anyway. And a state can never be 'coerced' to do something that it does not have to do by means of an act of retorsion, because the state resorting to retorsion has a right to act in the way that it does. In that, the analysis confirms the distinction drawn above in section two between unlawful coercion/intervention and lawful pressure/interference: the dividing line is determined by the international obligations a state has assumed, which in turn define the scope of its protected sphere of freedom (from economic coercion, among others).

The only way out of the conundrum would be perhaps to rely on the open-ended limit to countermeasures referring to obligations under peremptory norms of general international law, mentioned already above. ${ }^{46}$ If a sphere of economic freedom could be established as being protected by such a peremptory norm, incursion into this sphere would never be an act of retorsion, as the norm would impose a correlative duty or obligation on all states to respect the protected sphere of economic freedom. Further, such incursion would never be justifiable as a countermeasure either, as the latter may not affect obligations under peremptory norms of general international law. But this assertion would open a whole other can of worms: the one that involves demonstrating that such a sphere of economic freedom for each state has been 'accepted and recognised by the international community of States as a whole, as a norm from which no derogation is permitted. ${ }^{47}$ This is a different question altogether; before we launch into it (though it is always best to avoid it), perhaps an analysis of the law on economic sanctions may help find some other anchor for the purported fundamental right of freedom from economic coercion.

\section{The limits of (economic) sanctions}

The UN Security Council may impose (economic) sanctions on a state when it determines the existence of a threat to the peace, breach of the peace, or act of aggression, in order

46 ILC Articles on State Responsibility, art 50(1)(d).

47 cf VCLT, art 53. 
to maintain or restore international peace and security. ${ }^{48}$ Those (economic) sanctions, which may extend (and have occasionally extended) to the 'complete (...) interruption of economic relations, ${ }^{49}$ may have significant economic effects on the target state, as they did for example in the case of the comprehensive economic sanctions against Iraq following Iraq's invasion of Kuwait. Determining the limits of such sanctions may help discern a core sphere of economic freedom of the state, intrusion into which would constitute a violation of the state's fundamental right to be free from economic coercion.

In apparent sharp contradistinction to countermeasures, sanctions are not, strictly speaking, a reaction to illegality, ie a means of law enforcement. The UN Security Council does not impose sanctions in order to enforce the law against a recalcitrant state. It imposes sanctions in order to maintain or restore international peace and security. Indeed the whole of chapter VII of the UN Charter is drafted in such a way as to avoid reference to the target of the measures. The UN Security Council 'may decide what measures not involving the use of armed force are to be employed to give effect to its decisions, and it may call upon the Members of the United Nations to apply such measures. ${ }^{50}$ The only reference to a target state in the whole of chapter VII is in article 50 of the UN Charter, which provides that ' $\mathrm{i}] \mathrm{f}$ preventive or enforcement measures against any State are taken by the Security Council, any other State (...) which finds itself confronted with special economic problems arising from the carrying out of those measures shall have the right to consult the Security Council with regard to a solution of those problems. ${ }^{51}$

If, following the line of thinking presented in the foregoing paragraph, sanctions were not to be considered as a law enforcement tool, they would not be subject to the same limits as countermeasures. However, it could easily be argued that by providing for the imposition of sanctions in response to a threat to the peace, the UN Charter itself turns sanctions into a law enforcement tool. According to Kelsen, the content of a rule is that, the opposite of which is made the condition of a sanction. ${ }^{52}$ As the condition of the sanction in the circumstances is posing a threat to the peace, it can be argued that the UN Charter imposes a general obligation on states (but not necessarily exclusively on states) not to act in such a manner as would pose a threat to the peace. The obligation then not to pose a threat to the peace may be conceived as a blanket obligation (Blankettverpflichtung) ${ }^{53}$ to be concretised by the UN Security Council in accordance with article 39. If that were the case, then some analogy to the law regulating countermeasures would be permissible.

48 See UN Charter, arts 39, 41.

49 ibid art 41.

50 ibid.

51 ibid art 50 (emphasis added).

52 See Kelsen, Introduction to the Problems of Legal Theory (n 1) 26-27.

53 On the concept of 'blanket obligations' or 'Blankettverpflichtungen', see HG Niemeyer, Einstweilige Verfügungen des Weltgerichtshofs: Ihr Wesen und ihre Grenzen (Robert Noske 1932) $41 \mathrm{ff}$. 
In any event, the easier way to discern the limits of (economic) sanctions is to look at the obligations incumbent upon the entity that has been conferred with the power to impose them. The UN is an international organisation with 'a large measure of international [legal] personality', and indeed objective legal personality. ${ }^{54}$ As an international person, it is subject to obligations. These may stem from any valid source of international obligations, ${ }^{55}$ including, self-evidently, treaties to which the UN is a party and customary international law. ${ }^{56}$ However, international obligations for an international organisation may also stem from its internal law, in particular its constitutive instrument, ${ }^{57}$ an international treaty (to which of course the organisation is not a party-but to which it is not really a third party either). ${ }^{58}$ A detailed analysis of international obligations stemming from the UN Charter, from general international law and incumbent upon the UN when resorting to sanctions has been undertaken elsewhere. ${ }^{59}$ Suffice it to (re-)state here in summary fashion that the relevant obligations include the obligation to determine the existence of a threat to the peace, and the obligation to respect the principle of proportionality (both of which stem from the UN Charter), as well as obligations under customary international law, including obligations arising from peremptory norms of international law and obligations for the protection of human rights.

As in the case of countermeasures discussed in the preceding section, none of these limits seem to refer, per se, to any hard core of economic freedom in which the UN Security Council may not intrude. As such, there is no evidence of any fundamental right of states to be free from economic coercion: the UN Security Council may indeed 'coerce' them to do almost anything in order to maintain or restore international peace and security, as long as it respects the limits of its own competence (imposed by the UN Charter) and the obligations of the UN under customary international law, including peremptory norms. What is more, according to article 2(7) of the UN Charter, the principle of non-intervention in matters that are 'essentially within the domestic jurisdiction of any State' does not apply to the UN Security Council when acting under chapter VII of the UN Charter, including when it is imposing (economic) sanctions. As such, the only potential argument that can be made is that the fundamental right to be free from economic coercion constitutes a peremptory norm of international law, which is absolutely binding on the UN and thus on the UN Security Council when imposing sanctions. But then all this does is open that can of worms that we have been studiously trying to avoid up until now.

54 Reparation for Injuries Suffered in the Service of the United Nations (Advisory Opinion) [1949] ICJ Rep 174, 179.

55 See Articles on the Responsibility of International Organizations (2011) ILC YB 2011/II(2), art 10; cf ILC Articles on State Responsibility, art 12.

56 cf Statute of the International Court of Justice (adopted 26 June 1945, entered into force 24 October 1945) 1 UNTS 16, art 38(1).

57 ILC Articles on State Responsibility, art 4.

58 Elisabeth Zoller, 'The "Corporate Will” of the United Nations and the Rights of the Minority' (1987) 81 AJIL 610, 625.

59 See generally Tzanakopoulos (n 34) ch 3. 


\section{An essential and irreducible freedom from economic coercion?}

The existence of a fundamental right of states to be free from economic coercion, if it is to have any real content and purchase, cannot be defined purely negatively and residually. ${ }^{60}$ A residual right cannot be a fundamental right, as it has no stable ('hard') core, it is subject to constant readjustment, and it is relative even between different states (depending on the different international obligations they have undertaken). The right must be shown to be part of the 'sphere of freedom' that states enjoy, ie that essential and irreducible sphere which is somehow related to sovereignty and thus may be positively defined-though it does not appear that anyone, as of yet, has managed to properly positively define it to general satisfaction (and acceptance).

A review of the sources on the issues of essential and/or irreducible and/or exclusive sphere of freedom of states, whether called 'jurisdiction' (domestic or internal, and external), 'sovereignty', or 'domaine réservé, does not help. For every utterance of, say, the ICJ on the reserved domain, confirming that it is to be seen as residual and relative, there will be one other utterance of the same Court that will seem to imply that there is some sort of irreducible core of sovereignty which the state cannot dispose of. These two utterances can be found in the Nationality Decrees and Nicaragua cases, respectively. ${ }^{61}$

The law seems to comport with this: an analysis of the law on countermeasures and sanctions (and their respective limits) is barely comprehensible against an assumed fundamental right to be free from economic coercion with a positive, objectively definable content. In fact, states may be coerced as much as the coercing state(s) or international organisation(s) like, including economically (and even militarily), as long as the 'coercion' does not otherwise constitute a breach of an international obligation, such as the one prohibiting the use of force. Even if it does violate an international obligation, coercion will still not be unlawful if it is justifiable under international law, in particular as a countermeasure (or through some other circumstance precluding wrongfulness).

Now the obvious problem here is the prohibition of intervention. The 'coercive' measure might breach the prohibition of intervention, thus rendering coercion unlawful. So any measure that constitutes intervention will be unlawful coercion, and vice versa. Didn't the ICJ say so in Nicaragua after all (while also implying that there might be some minimum positive content in the concept of the 'sphere of freedom' of states) $?^{62}$ Let us take a closer look at what the ICJ said there:

A prohibited intervention [as opposed to a permitted one, one wonders?] must accordingly be one bearing on matters on which each State is permitted, by the principle of State sovereignty,

60 See also the contribution by Stephen C Neff, 'The Dormancy, Rise and Decline of Fundamental Liberties of States' (2015) 4 CJICL 482.

61 Nationality Decrees (n 19) 24; Nicaragua (n 15) 98, para 205.

62 See Nicaragua (n 15) 98, para 205. 
to decide freely. One of these [matters] is the choice of a political, economic, social, and cultural system, and the formulation of foreign policy. ${ }^{63}$

The ICJ seems to identify at least part of the core area of matters on which a state is permitted, by the principle of State sovereignty, to decide freely. ${ }^{64}$ That part is the one referring to the 'choice of a political, economic, social, and cultural system, and the formulation of foreign policy. ${ }^{65}$ So, is this part of the irreducible core of the sphere of freedom of the state, which the state cannot dispose of even in the exercise of its sovereignty? And does it imply that we may be able to find other parts of the core of that sphere?

The answer, I am afraid, is 'no', and the ICJ, if its judgment in Nicaragua is read in the way the preceding paragraph suggests, is wrong. This is because even the matters of choice of a political or economic or social or cultural system, and of formulation of foreign policy may be regulated by international law, and thus be put outside the sphere of freedom of the state. Can a state adopt a foreign 'policy of force'? Not according to Corfu Channel, ${ }^{66}$ and not according to the UN Charter. ${ }^{67}$ Can a state adopt a political, social, and cultural system based on racial discrimination? Clearly not. ${ }^{68}$ There are even claims that new states can no longer emerge unless they are democratic, and that democratic governance is arising as an obligation under international law. ${ }^{69}$ And so states are not free to choose their political or economic or social or cultural system, or to formulate their foreign policy. They are only free to do so to the extent that they have not assumed obligations, in one way or another, not to do so.

A striking case study could be the Greek sovereign debt crisis and the battle of the Greek state with the troika of creditors, the International Monetary Fund, the European Central Bank, and the European Commission. The Greeks, having assumed international obligations to impose harsh austerity in the form of loan agreements and associated 'memoranda of understanding' between 2010 and 2015, were quite openly coerced by the institutions into complying with these obligations in full, even when this made little economic or other sense. ${ }^{70}$ When the left wing SYRIZA party was elected to form

63 ibid (emphasis added).

64 ibid.

65 ibid.

66 See Corfu Channel (United Kingdom v Albania) (Merits) [1949] ICJ Rep 4, 35.

67 UN Charter, art 2(4).

68 See International Convention on the Elimination of All Forms of Racial Discrimination (adopted 21 December 1965, entered into force 4 January 1969) 660 UNTS 212 (regarding the prohibition of racial discrimination as a jus cogens rule, see also Orakhelashvili (n 37) 53ff, 268-70); International Convention on the Suppression and Punishment of the Crime of Apartheid (adopted 30 November 1973, entered into force 18 July 1976) 1015 UNTS 243.

69 For a discussion of an allegedly emerging right of democratic governance, see generally Thomas M Franck, 'The Emerging Right to Democratic Governance' (1992) 86 AJIL 46.

70 See, eg, Paul Krugman, 'Killing the European Project' New York Times (12 July 2015) <http://krugman. blogs.nytimes.com/2015/07/12/killing-the-european-project/> accessed 16 November 2015; Simon Shuster, 'Joseph Stiglitz to Greece's Creditors: Abandon Austerity or Face Global Fallout' TIME (29 June 2015) <http://time.com/3939621/stiglitz-greece/> accessed 16 November 2015. 
a government in January 2015 on a platform that pledged to end the harsh austerity measures demanded by the creditors, the creditor institutions progressively turned off the liquidity tap, ${ }^{71}$ forcing the Greek state to eventually impose capital controls at the end of June 2015. ${ }^{72}$ Ultimately, the SYRIZA government had to request a new bailout, and it was forced to backtrack in a showdown 17-hour long negotiation in Brussels on 12-13 July 2015 under threat of being ejected from the Eurozone, and facing a default coupled with a financial and banking meltdown. In so doing, it accepted some rather burdensome international obligations, including an obligation to 'consult and agree' with the institutions on all draft legislation (on fiscal and other relevant matters) before submitting the legislation to the Greek parliament. ${ }^{73}$ The harsh demands that Greece was made to accede to were widely seen, including on Twitter worldwide, ${ }^{74}$ as an attempt at regime change. ${ }^{75}$ And yet, there does not seem to be an implication that the creditors have acted illegally in these circumstances-stupidly, perhaps, or rightly, or even (im) morally (depending on who you ask), but arguably not illegally. They were, in the first instance, merely seeking to induce Greece to comply with the obligations it had assumed (notably, under a different government), and then they were simply negotiating a new agreement using as much leverage as they could muster (and they could muster a lot), almost crushing the country in the process.

Things would be different if it could be shown that states possess a certain bundle of inherent rights which they are not entitled to dispose of freely in the exercise of their sovereignty. This would be difficult to argue in view of the fact that a state is entitled, after all, to even commit 'suicide. ${ }^{76}$ Statehood does indeed bestow upon states a certain set of 'rudimentary' rights, ie rights the states inherently possess merely by virtue of being states. ${ }^{77}$ These include the right of a state to political independence, including the right to choose any political, economic, social, and cultural system, the right to exercise jurisdiction, ie to organise itself as it sees fit, to legislate upon its interests, administer its services, and so forth, as well as certain other rights regarding participation in customary

71 See Claire Jones, 'Greek Stand-off Puts Draghi on the Political Stage' Financial Times (2 February 2015) <http://www.ft.com/intl/cms/s/0/f8525fbe-aaf6-11e4-91d2-00144feab7de.html> accessed 16 November 2015.

72 See Brian Blackstone, Nektaria Stamouli and Charles Forelle, 'Greece Orders Banks Closed, Imposes Capital Controls to Stem Deposit Flight' Wall Street Journal (28 June 2015) <http://www.wsj.com/articles/ SB11064341213388534269604581075703841095260> accessed 16 November 2015.

73 Euro Summit Statement (12 July 2015) SN 4070/15 <https://www.consilium.europa.eu/en/press/pressreleases/2015/07/pdf/20150712-eurosummit-statement-greece/> accessed 16 November 2015.

74 The relevant Twitter hashtag is \#ThisIsACoup. On the night of 12-13 July 2015, the hashtag was trending in the top three in most European capitals, the United States and worldwide. See 'Why Was \#ThisIsACoup Trending?’ BBC News (13 July 2015) <http://www.bbc.com/news/world-europe-33505622> accessed 16 November 2015.

75 Robert H Wade, 'EU Attempts a Coup d'État by Stealth in Greece' Financial Times (17 June 2015) <http:// www.ft.com/cms/s/0/95afe0c6-14ea-11e5-a51f-00144feabdc0.html> accessed 16 November 2015.

76 Florence Poirat, 'La Doctrine des Droits Fondamentaux de l'Etat' (1992) 16 Droits: Revue Française de Théorie Juridique 83, 91.

77 Stefan Talmon, 'The Constitutive Versus the Declaratory Theory of Recognition: Tertium Non Datur?' (2004) 75 BYBIL 101, 148. 
law creation, granting of nationality, determining the breadth or declaring the existence of certain maritime zones, and reacting against violations of its rights. ${ }^{78}$ At any rate, even these rudimentary rights that inhere in statehood may be both limited in the exercise of sovereignty and denied to the state by way of countermeasures. ${ }^{79}$

This means that there are barely any fundamental rights of states in any meaningful sense, let alone any fundamental right to be free from economic coercion. All is relative. This may sound extremely downbeat and disappointing. But it is not. These are the possibilities and limits of positive law: if we are not to slip into naturalism (and that is a dangerous route indeed), some perspective is direly needed. Positive law is not here to cure the world of its ills. It is mostly here to reflect those ills, and it does so in particular when it comes to 'fundamental rights' of states. Any discussion of fundamental rights of states thus should not be seen as some independent legal category, but at best as an argumentative practice or as a narrative of resistance. As Lowe has said,

Lawyers have a contribution to make. They offer one way of going about resolving some of the most crucial problems that face the world. But it is only one way among many. There are many times when it is much better to call upon a politician, or a priest, or a doctor, or a plumber. ${ }^{80}$

Indeed, the way to cure the world of this ill is politics, in particular, political struggle. Politics can establish fundamental rights of states as a legal category; political struggle can change the law. And the people can change politics, even if with great difficulty. But in the meantime, labouring under the illusion that the law poses some outer limit to evil in this case merely deflects our energy from where it is needed: political activism and political struggle. You want to know if there is a fundamental right of states to be free from economic coercion? There is not, unless you can identify some specific obligation that has been breached on the part of the reacting state or international organisation. This is not surprising, mind you, in a world where (casino) capitalism reigns supreme. ${ }^{81}$ Do you want there to be a fundamental right of states to be free from economic coercion? Splendid! Go out there and make one.

80 Vaughan Lowe, International Law (OUP 2007) 290 (emphasis added).

81 That is really the only kind of capitalism there can be. I thank Haris Triantafyllidou for bringing this obvious point to my attention. 